\title{
Ortodontik interseptif: efektivitas rapid palatal expander pada crowding gigi anterior pada anak

\author{
Interceptive orthodontics: effectivity of rapid palatatal expander in children with \\ anterior teeth crowding
}

\author{
Harun Achmad, Hendrastuti Handayani \\ Bagian Ilmu Kedokteran Gigi Anak \\ Fakultas Kedokteran Gigi Universitas Hasanuddin \\ Makassar, Indonesia
}

\begin{abstract}
Interceptive orthodontic treatment aims to reduce and improve the causes of malocclusion in the stage of growth and development that may have a bad effect in the future. Dental crowding is a state of the disproportion between the size of the teeth, jaw size and arch length. There are three conditions that facilitate the crowding, the width of the teeth, small jaw basal bones or a combination of both. One of the techniques of handling the case of children anterior crowding due to disproportion size of tooth width with a narrow arch is the rapid palatal expander device (RPE) in order to obtain the ideal space for the teeth and arch length. A boy, aged 11 years, wants to be treated his teeth with complaints teeth of front upper jaw and lower jaw experiencing crowding, thereby disrupting the appearance and mastication. Almost all the permanent teeth have erupted, and the jaw is still in its infancy. The treatment is carried out with a combination of fixed orthodontic devices and RPE for 4 months of treatment, showed a positive change in the profile seen in clinical oral cavity conditions of patients.
\end{abstract}

Keywords: orthodontic interceptive, anterior crowding, rapid palatal expander

\begin{abstract}
ABSTRAK
Perawatan ortodontik interseptif bertujuan untuk mengurangi dan memperbaiki penyebab terjadinya maloklusi pada masa tumbuh kembang yang mungkin mempunyai pengaruh yang lebih buruk di masa mendatang. Gigi crowding merupakan suatu keadaan terjadinya disproporsi antara ukuran gigi, ukuran rahang dan panjang lengkung. Ada tiga keadaan yang memudahkan terjadinya crowding, yaitu lebar gigi yang besar, tulang basal rahang yang kecil atau kombinasi dari keduanya. Salah satu teknik penanganan kasus anterior crowding anak akibat disproporsi ukuran gigi yang lebar dengan lengkung rahang yang sempit adalah dengan piranti rapid palatal expander (RPE) dengan tujuan untuk mendapatkan ruang yang ideal untuk gigi dan panjang lengkung rahang. Seorang anak laki-laki, umur 11 tahun, ingin dirawat giginya dengan keluhan gigi depan rahang atas dan rahang bawah mengalami crowding, sehingga mengganggu penampilan dan pengunyahan. Hampir semua gigi permanen telah erupsi, dan rahang masih dalam proses pertumbuhan. Perawatan yang dilakukan dengan kombinasi piranti ortodontik cekat dan piranti RPE selama 4 bulan perawatan, didapatkan perubahan profil positif yang tampak pada keadaan klinis rongga mulut pasien.
\end{abstract}

Kata kunci: ortodontik interseptif, anterior crowding, rapid palatal expander

Koresponden: Harun Achmad, Bagian Ilmu Kedokteran Gigi Anak, Fakultas Kedokteran Gigi Universitas Hasanuddin, Jl. Perintis Kemerdekaan Km.10, Makassar, Indonesia. E-mail: 